\title{
The Transformation of Kampung Arab Al-Munawarah Becomes a Tourism Object
}

\author{
Nuranisa and Eni Heldayani \\ Geography Education Study Program, \\ Faculty of Teacher Training and Education, PGRI University of Palembang \\ Email: nuranisageo@gmail.com
}

\begin{abstract}
The objective of this research is to identify the impact of transformation of Kampung Arab Al-Munawar Palembang into a tourism object. The writer uses the qualitative and descriptive method in this research. The data collected through survey method is by interviewing samples selected randomly to observe the effects of transformation and development experienced by development of Kampung Al-Munawar both socio-cultural and economic aspect of the community. The results of this research shows that the transformation of Kampung Al-Munawar has a positive effect on physical form of dwelling, economic, and social cultural aspects of the community. The forms of residental houses are going to be more beautiful and well maintained. The economy seems to be more always, with the appearance of several new ventures of community. Community became more consistent to maintain the customs and habits of Kampung Al-Munawarin in order not to be contaminated with the habits of visitors. Culture of the community is growing and preserved so that it can be known by the domesticpublic and overseas.
\end{abstract}

Keywords:Transformation, Tourism Village, Kampung Al-Munawar

\section{Introduction}

Various attempts were made to preserve the cultural heritage that became evidence of the existence civilization from the past. The government of South Sumatera always keeps the existence the ethnic village in Palembang as it is an evidence of the arrival of other nations to Palembang. As a cultural heritage, ethnic village in Palembang deserve to be preserved to maintain beneficial for the next generation. In order to maintain the cultural heritage, ethnic village has the attention by government of Palembang, the government transforming the form of ethnic villages in the of Palembang. Ethnic village in the Palembang transformed became a cultural and religious tourism village.

One of the ethnic villages that have been inaugurated by government of Palembang into a cultural and religious tourism village is Kampung Arab Al-Munawar. Kampung Al-Munawar is a village occupied by Arabs who have the tribe of Al-Munawar. Kampung Al-Munawar is an Arab village that still maintains homogeneity, cultural tradition and hereditary houses to show the identity of Arab nation for the first time. Kampung Al-Munawar was founded by Habib Abdurrahman Al-Munawwar who came from Hadramaut, South Yemen at the beginning of the 18th century (Purwanti, 2017).

The transformation of Kampung Al-Munawar into a tourism object will involve the Al-Munawar community into tourism activities, so they have a great impact on various aspects of life, both in economic, social and cultural of society. Tourism economy provides new business opportunities and jobs. According to Yoeti (2008), the positive impact of tourism development on the economy of society can be seen from tourism activities such as tourists need services, from the need can provide an opportunity to try, increase employment and increase income and speed up the distribution of people's income. Social culture of community is a way of life including the way they live, work, play and interact to each other. 
Richardson and Fluker (in Pitana and Diartara, 2009), mentions the impact of tourism on socio-cultural life, there are the impact on the population structure (the job change from other sectors to the tourism sector), transformation of livelihood structures (job opportunitiesof tourism sector have to advantages rather than other sectors so others peopleinterested in tourism sector), the transformation of the values (the increase of population by the arrival who have of different attitude which result in the mixing of norm tourist destination). In relation to the conditions, the development of tourism has an urgent impact on the economic and social life related to the culture in tourism destination area, the object of this research is to find out and describe how the effect of the transformation of Kampung Al-Munawar to be one of the cultural and religious tourism objects in the Palembang.

\section{Method}

The writer uses qualitative and descriptive method in order to describe clearly the conditions of socio-cultural and economic effects at Kampung Al-Munawar community. The data collected is through the survey method by interviewing people selected randomly to observe the effect of transformations an development of Kampung Al-Munawar both socio-cultural and economic aspects of the community. The writer also uses observations through renovated buildings and archival data (photos, books, journals).

\section{Results and Discussion}

Kampung Al-Munawar is an ethnic Arab village (kampung) located in Palembang City inaugurated as one of the cultural and religious tourism objects in Pelambang, due to its beauty and uniqueness. It is also one of the studies for research and development. It was inaugurated as a tourism object on Saturday, February 11, 2017 by governor Alex Noerdin in order to welcoming the Asian Games in 2018. To prepare Kampung Al-Munawar as one of the tourism attractions in Palembang city, the ministry of tourism began to manage and maintain Kampung Al-Munawar. The management of Maintenance is physically visible from the transformation of Kampung Al-Munawar, houses that are hundreds of years old which began to fragile and dull, maintained and improved without eliminating the original impression and characteristic of the building as the icon of cultural tourism and religious area. Through the maintenance of Kampung Al-Munawar, it now looks cleaner and more beautiful. The provision of seating and potted plants next to the house makes the houses more beautiful. Kampung Al-Munawar looks cleaner and more attractive.

The transformation and development could be positive and negative. The positive effect is Kampung Al-Munawar to be the icon of the cultural and religious tourism object, so that it looks more beautiful more impressive, cleaner and comfortable. However, it has also a negative effect related to the historical aspect, the painting of the houses will look like new buildings, now the old impression of buildings is no longer visible. As a tourism object (village), the local community must firstly be educated. the community of Kampung Al-Munawar must be educated that it is a tourism object and they should be ready to be aware of the changes at Al-Munawar. Putri and Ariani (2011) mentioned, "seven enchantment called Sapta Pesona that must be have by society of tourist destination area which can increase tourist attraction, there are Feeling Safe, Orderly, Clean, Cool, Beautiful, Friendly and Fun." The seventh element of Sapta Pesona tourism should be applied into tourism destinations so that the tourists feel comfortable. If a region is transformed into a tourism area, it could improve economic, social and cultural life.

\section{Economic Transformation}

The transformation of Kampung Al-Munawar has a lot of positive effects for local community, a new employment and the increase of income. According to Mill in his book, The Tourism, International 
Business (2000), states that tourism can provide benefits for tourists and the host community and can raise the livingstandard through the economic benefits brought to the region. The visitors visiting Kampung Al-Munawar give opportunities job and a new business. As disclosed by Yoeti (2008), that the most positive impacts of tourism is economic aspect, where "tourism can create employment and business opportunities, can increase incomeat the same timecan accelerating the income average of community, increasing tax acceptance, increasing national income, and strengthen the balance of payments. There are new jobs vacancy at Kampung Al-Munawar community, such as parking attendants, ticket guards, and tour guides. New types of businesses come up are food, beverages, and hena house.The staple food are also provided, such as empek-empek, model, tekwan, fried food and snackspackaged. The drinks, of Kampong Al-Munawar has a certain brand, Sendok Mas which is a typical drink from this village. Sendok Mas coffe served with a gold teapot and a small glass that can be drunk with Rp 5000 rupiah only. Aside coffee there are also other common drinks provided and can be enjoyed by visitors.

Kampung Al-Munawar community has not provided, the Kampung Al-Munawar typical food usually served during a regular Munggahan ceremony to celebrate the wedding, Such as nasi kebuli, nasi briyani, chicken curry, and meat curry. The food is only provided for very important guests visiting Kampung Al-Munawar. When visitors who come to enjoy the beauty of Kampung Al-Munawar, there are also visitors who come as a coach and researcher at Kampung Al-Munawar. The coaching and research activities improve the community income. The economic effect of people at Kampung Al-Munawar has not maximum yet. Although many visitors visit, the income of the community has not fully improved because the sale value of seller who has taken advantage of this development is still low and decreased daily income. It is different from in kampung Al-Munawar has certain events. In This occasion, most of visitors enjoy the beauty of Kampung Al-Munawar by taking pictures, and enjoying the views. The visitors will directly leave because it has in complete facilities. The fewer facilities, the fewer tourists will stay longer at Kampung Al-Munawar. The government and the ministry of tourism must be able to find out the solution In order to appeal more tourists and make them stay longer in Kampung Al-Munawar, there must be great tourist attractions and complete fasilities. What we should do is the availability of recreational facilities, the availability of shopping facilities, especially souvenir items and people's crafts as souvenirs, the accessibility, such as public transport and vehicles that can bring visitors to the tourist destinations. What to stay is the existence of lodging facilities for tourists stay while on vacation (Maryani, 1991). The convenience of visitors, and the stuff/food price should be major concerns. the objects must be managed and monitored properly, it is also associated to community attitude because it is related to the community, The price should not be too high so that it could make the visitors interested.

\section{Social Impact}

Social impact is an essential attempt to determine the effect in community related to new activity or a certain physical change. This estimation is important because it is closely related to the advantages and disadvantages through the environmental changes. By doing this analysis the effect will firstly be observerd. the book of Laporan Eksekutif Penelitian Dampak Sosial Budaya Pembangunan Pariwisata (1999) Gadjah Mada University, "social aspects of human life are social relations, social trelationship which is an abstraction of interaction that occurs between individuals to each other, such as cooperation, conflict, and participation." In terms of social life, there could be positive and negative effect. Then how about Kampung Al-Munawar? Kampung Al-Munawar community still exists and maintains its identity. The local people are still friendly to welcoming visitors. Those who usually only interact to their fellow residents and the local people, now they interact to people who come from all areas. The People feel happy because they can meet and gain experience from the guests who come. Nevertheless, the life of people in that area is not changing. The social life of the community in Kampung Al-Munawar is still good even better as the object of cultural and religious tourism. The interaction between individual with the other in the village is not changing. 
Cooperation and gotong royong are still preserved. and the community still participates in any kinds of traditional events or organization in Kampung Al-Munawar, such as, series of regular assemblies at the mushollah Al-Munawar which was located riverside of the Musi River, a series of assemblies held in the mushollah. The schedule and type of assemblies are in the brochures distributed when we visit Kampung Al-Munawar. Negative impacts of tourism development for the social life of the the tourist destination community is community could be affected due to the tourists' habit and customs. Being acceptance without selection will bring negative impacts to the social and cultural life of the community in the tourist destination. So far, the peoples of Kampung Al-Munawar are still able to maintain their identity without being affected by the visitors. Peoples of Kampung Al-Munawar are welcoming any visitors. They are set to interaction to visitors, being friendly and open mindedness. But still uphold the togetherness in the village, still doing cooperate and gotong royong, and doing Kampung Al-Munawar customs any time.

\section{Cultural Impact}

Cultural tourism is a journey which is done with the urge to broaden people view of life by making trip from one to other places, studying situation, customs of society, the way of life, the culture and their art. This trip is usually done by tourists to take the opportunity to be the part in cultural activities such as dance, drama, music, and voice art or activities that have historical motifs and so on (Pendit, 1994). One positive impact of the cultural aspect is cross-cultural understanding, mutual respect relationships and understanding among nations from other countries in different cultural backgrounds. The opportunity to exchange thoughts rather than to satisfy curiosity. Tourism also promotes both international credibility and cultural worth (Denis L.foster, 2000). The people of Kampung Al-Munawar are a homogeneous society and expand a culture adapted from the culture, the native country and local culture. Congenital culture from their native country is the language and art of dance (Zapin). Zapin dance usually performed during Haul and wedding ceremonies. The tradition of Haul Habib Abdurrahman Al-Munawar (village founder) is held every 7 Rajab. The uniqueness in the performance of the Haul is existence of ceremony Ijab Kabul couples of bride as many as 2-8 pairs of brides. then, the newly married couple were then paired in the "Rumah Kembar Laut". Until the late 1990s, the groom was invited to Zapin dance by the youths in the front yard of " Rumah Kembar Laut ". Then the groom is thrown into the Musi River. Wedding outfits they put on is a traditional wedding dress of Palembang.

Another local culture is the variety of Palembang original (certain characteristic) food. Moreover is the tradition of Rumpak-Rumpak, that is visiting tradition to the ulama place, Habib or Syeikh, in every celebration Eid Fitri or Eid Adha, is still maintained and ancient houses in Kampung Al-Munawar aged more than 100 years so that it is reasonable if it has a little bit damaged in certain parts of house, especially those made by wooden. At Rumah Darat, damages appears on floor, frames and windows, and parts of walls. Meanwhile, houses made by stone having damaged in the wall that had cracks and tiles broke (Purwanti, 2017). One of the wisdoms having been taken by the government and supported by the community is the establishment of the Al-Munawar Coffee Festival. Data found in the field, the transformation of Kampung Al-Munawar into a cultural and religious tourism object has a positive impact on the culture of the community. the forms of local culture exist and maintain at Kampung Al-Munawar until now, preserved, and developed into an icon for tourism attractions and introduced to the public, both in the domestic and abroad. Besides, it includes in the worth system, norms and faith of Kampung Al-Munawar community which are also well maintained. In terms of worth, norms and faith of the people of Al-Munawara really keep from the impact coming from outside, it is clearly visible from the brochures distributed to visitors while entering the gate of Kampung Al-Munawar. There are clearly visible rules that must be obeyed by visitors, for example the rules stated that visitors must not get along with to those who are not legally married. The visitor's outfit should be proper and compatible in accordance with Syari'ah Islam. The Activities and customs of Kampung Al-Munawar have already been listed on the brochure. If there are 
visitors who are not dressed appropriately, then they will be lent additional outfit such as sarongs and body coverings that have been provided at the reception post.

\section{Conclusion}

The objective if this research is to identify the impact of transformation of Kampung Arab Al-Munawar Palembang into a tourism village. The impact of the transformation of Kampung Arab Al-Munawar into a tourism village will have an impact on the economic, social and cultural life of the community. This research shows that the changes affected significant impacts. Whether it is a positive or a negative impact. From the economic sector there are new job opportunities and increase of community income. However, economic development has not fully been able to support the community because there are a few visitors who spend the money there because there are not any factors that make them want to stay longer in Al-Munawar. In terms of social point, Al-Munawar community is still able to maintain their relationships and interactions to the local community even though they have begun to interact and overt to welcoming visitors who come to Kampung Arab Al-Munawar. In terms of a cultural points, the cultural existance at Kampung Arab Al-Munawar becomes more developed and well maintained.

\section{References}

Dennis L. Foster. (2000). An Introduction Travel \& Tourism. edisi bahasa indonesia, Raja Grafindo Persada, Jakarta.

E, Maryani. (1991). Pengantar Geografi Pariwisata. Jurusan Pendidikan Geografi FPIPS IKIP Bandung.

Laporan Eksekutif Penelitian Dampak Sosial Budaya Pembangunan Pariwisata. (1999). Universitas Gadjah Mada.

Mill, R.C. (2000). The Tourism: International Business. NJ: Prentice Hall.

Yoeti, Oka A. (2008). Ekonomi Pariwisata Introduksi, Informasi, dan Implementasi. Jakarta: PT. Kompas Media Nusantara

Pendit, Nyoman S. (1994). Ilmu Pariwisata: Sebuah Pengantar Perdana. Jakarta: Pradnya Paramita.

Putri, T dan Ariani, M. (2011). "Penerapan Sadar Wisata dan Penguatan Citra Wisata Melalui Penanaman Tanaman Upakara di Kerambitan Kabupaten Tabanan". Jurnal Udayana Mengabdi.

Purwanti, Retno. (2017). Pelestarian Kawasan Kampung Arab Almunawar Palebang.Sumatera Selatan. Seminar Heritage IPLBI.

Pitana, I Gede dan Diarta, I Ketut Surya. (2009). Pengantar Ilmu Pariwisata. Yogyakarta: CV.Andi Offset. 